\title{
Air Entrainment and Pressure Fields over Stepped Spillway in Skimming Flow Regime
}

\author{
Anant I. Dhatrak, Sandip P. Tatewar \\ Department of Civil Engineering, Government College of Engineering, Amravati, India \\ Email: anantdhatrak@rediffmail.com, sandiptatewar@yahoo.co.in
}

Received December 2013

\begin{abstract}
This paper deals with some aspects of the air entrainment process along the chute of spillway and study of pressure fluctuations. The experimental study has been carried out using stepped spillway model located in the campus of Government College of Engineering, Amravati (India). It is observed that air concentration is increasing with discharge as well as with number of step. Air concentration is increasing along the length of spillway. It is also observed that the bottom mean air concentration increases with step height in the upstream reach of stepped spillway, which is prone to cavitation. The pressure profiles exhibit a wavy pattern down the stepped chute and pressure on each step increases with ratio of critical depth to step height $\left(\mathrm{y}_{\mathrm{c}} / \mathrm{h}\right)$.
\end{abstract}

\section{Keywords}

\section{Stepped Spillway; Air Entrainment; Skimming Flow Regime; Pressure Fluctuations}

\section{Introduction}

Stepped spillways have been used for many centuries. The stepped spillway consists of series of steps provided from just below the crest to the toe of spillway. The stepped design increases the rate of energy dissipation on the surface of spillway and there by reduces the size of stilling basin generally provided at the toe of spillway. The flow over stepped spillway is broadly classified into two types: 1) Nappe flow and 2) Skimming flow. In case of nappe flow, the flow from each step hits the step below as a falling jet. In case of skimming flow regime, the water flows down the stepped face as a coherent stream, skimming over the steps and cushioned by the recirculating fluid trapped between them. Along the upstream steps, the flow is smooth and no air entrainment occurs. Downstream the flow is characterized by a large amount of flow aeration. The air entrainment starts where the boundary layer reaches the outer edge of the free surface and this point is called point of inception. Downstream of the point of inception, the flow becomes rapidly aerated and presents a typical white surface. This paper deals with some aspects of the air entrainment process along the chute of spillway and study of pressure fluctuations.

\section{Experimental Test}

A model of stepped spillway has been constructed in the premises of Government College of Engineering, 
Amravati (India). The stepped spillway model, $0.59 \mathrm{~m}$ wide, $2.46 \mathrm{~m}$ high, has 34 steps with step height $0.08 \mathrm{~m}$, and slope angle equal to $51.34^{\circ}$. The pressure values have been recorded by means of piezometers connected to middle of the tread of step numbers $5,7,9,14,19,24,29$, and 32 . Air concentration is measured by means of air concentration V-probe. In the model setup, V-probes are placed on the step numbers 9, 16, 23, and 27 for the measurement of air concentration.

\section{Measurement of Air Concentration}

The average air concentration (c) is measured for two values of discharge $0.040 \mathrm{~m} / \mathrm{s} \cdot \mathrm{m}$ and $0.0545 \mathrm{~m}^{3} / \mathrm{s} \cdot \mathrm{m}$. Buwa and Ranade [1] have given the details of the V-probe used in experimental setup. The trend of average air concentration with aerated flow depth $\left(\mathrm{y}_{\mathrm{a}}\right)$ in Figures 1 and $\mathbf{2}$ which is found to be similar with the trend presented in the paper of Boes and Hager [2]. Further it shows that air concentration increases with discharge as well as with number of step. Air concentration increases along the length of spillway.

\subsection{Study of Uniform Bottom Air Concentration on Stepped Spillway}

Pfister, M., Hager, W. H., and Minor, H. E. [3] investigated the uniform bottom air concentration on stepped spillway with experimental approach. They suggested Equation (1) for calculation of $\mathrm{C}_{\mathrm{bu}}$,

$$
\mathrm{C}_{\mathrm{bu}}=0.268-5.69 \times 10^{-3} \mathrm{~F}^{*} \text { for } \alpha=50^{\circ}
$$

Boes [4] suggested Equation (2) for calculation of $\mathrm{C}_{\mathrm{bu}}$,

$$
C_{b u}=0.75 \sin \propto-0.3-\left(1.8 \times 10^{-2} \sin \propto-8.1 \times 10^{-3}\right) F^{*} \text { for } 26^{0}<\propto<55^{0}
$$

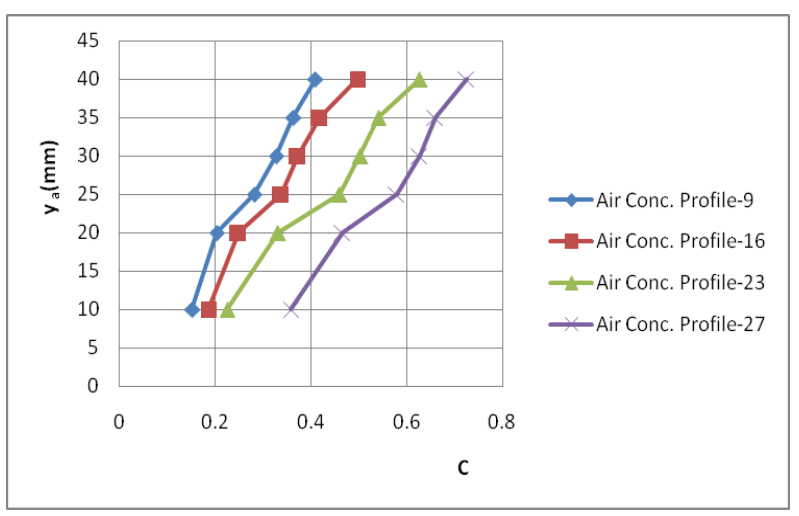

Figure 1. Air concentration profiles on stepped spillway model $\left(q=0.0400 \mathrm{~m}^{3} / \mathrm{s} \cdot \mathrm{m}\right)$.

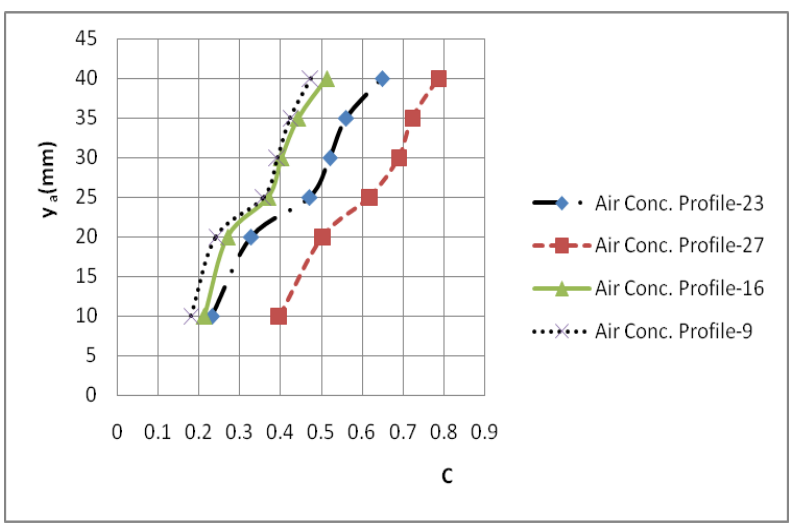

Figure 2. Air concentration profiles on stepped spillway model $\left(q=0.0545 \mathrm{~m}^{3} / \mathrm{s} \cdot \mathrm{m}\right)$. 
where

$$
\begin{gathered}
F^{*}=\frac{q}{\sqrt{\left(g \times \sin \propto \times k_{s}^{3}\right)}} \\
k_{s}=(h \times \cos \propto)
\end{gathered}
$$

where $\alpha$ is downstream slope/chute angle of spillway. Figure 3 compares $\mathrm{C}_{\mathrm{bu}}$ calculated from Equations (1) and (2). Both the equations show the good agreement with observed values of Boes.

\subsection{Effect of Step Height on Mean Bottom Air Concentration}

The effect of step height on mean bottom air concentration is studied by using Equation (3) [4] for minimum discharge of $0.109 \mathrm{~m}^{3} / \mathrm{s} \cdot \mathrm{m}$ and maximum discharge of $0.866 \mathrm{~m}^{3} / \mathrm{s} \cdot \mathrm{m}$.

$$
\mathrm{C}_{\mathrm{bm}}\left(\frac{\mathrm{y}_{\mathrm{c}}}{\mathrm{h}}\right)=0.1 \times 10^{-0.035 \mathrm{n}}
$$

Figures 4 and 5 show the variation of $C_{b m}$ with step numbers " $n$ ”.

It is observed that there is increase in $C_{b m}$ with step height for $n=0$ and this effect decreases with increase in value of “n”. Pfister [3] studied mean bottom air concentration with step height, $h=0.093 \mathrm{~m}$. The Authors selected the step heights $0.0775 \mathrm{~m}, 0.062 \mathrm{~m}$ and $0.0465 \mathrm{~m}$ for studying the effect of step height on $\mathrm{C}_{\mathrm{bm}}$. Figures 4 and 5 indicate that the mean bottom air concentration increases with step height in the upstream reach of stepped spillway, which is prone to cavitation. The trend of $\mathrm{C}_{\mathrm{bm}}$ variation with step height is same for the minimum and maximum discharge.

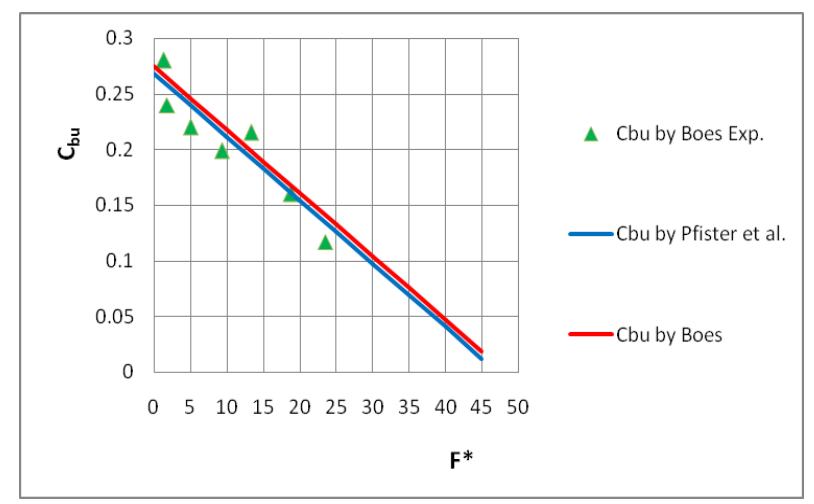

Figure 3. Comparison of uniform bottom air concentration $\left(\mathrm{C}_{\mathrm{bu}}\right)$.

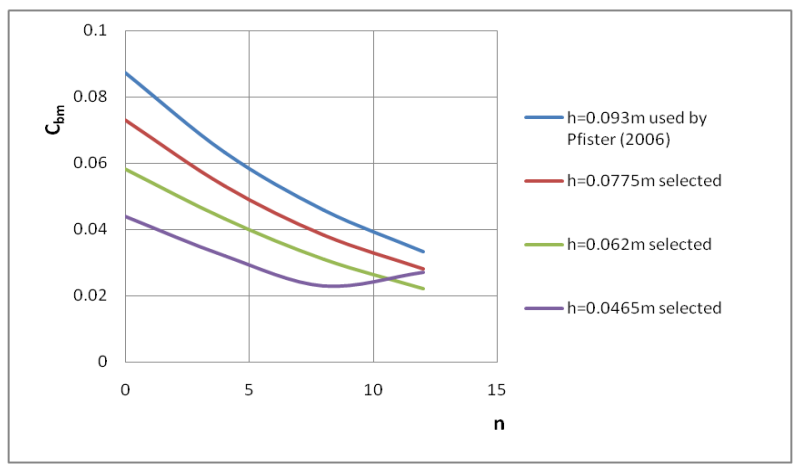

Figure 4. Variation of $C_{b m}$ with step number for $q=0.109$ $\mathrm{m}^{3} / \mathrm{s} \cdot \mathrm{m}$. 


\section{Measurement of Pressure Fluctuations on Stepped Spillway}

In case of stepped spillways the flow is highly turbulent and there is an every possibility of development of negative pressure on some of the steps which lead to cavitations. Therefore, it is necessary to measure pressure on each step of the stepped spillway. In this model study, the peizometric tubes are fixed on step numbers 5, 7, 9, 14, 19, 24, 29 and 32 and pressure was measured on the centre of horizontal face of steps.

\section{Measurement of Pressure Fluctuations}

Figure 6 shows the variation of measured pressure between the parameter $\mathrm{p} / \mathrm{h}$ and $\mathrm{Z} / \mathrm{H}$ on stepped spillway model for different values of $\mathrm{y}_{\mathrm{c}} / \mathrm{h}$, where $\mathrm{p}$ is the pressure head, $\mathrm{h}$ is the step height, $\mathrm{Z}$ is the vertical height from crest up to step of pressure measurement, and $\mathrm{H}$ is the height of spillway.

Similar pressure profiles had been presented by Matos, J., Sanchez, M., Quintela, A., and Dolz, J., [5] in skimming flow for a downstream slope of $1 \mathrm{~V}: 0.75 \mathrm{H}$ stepped chute. The Figure 7 shows the comparison of

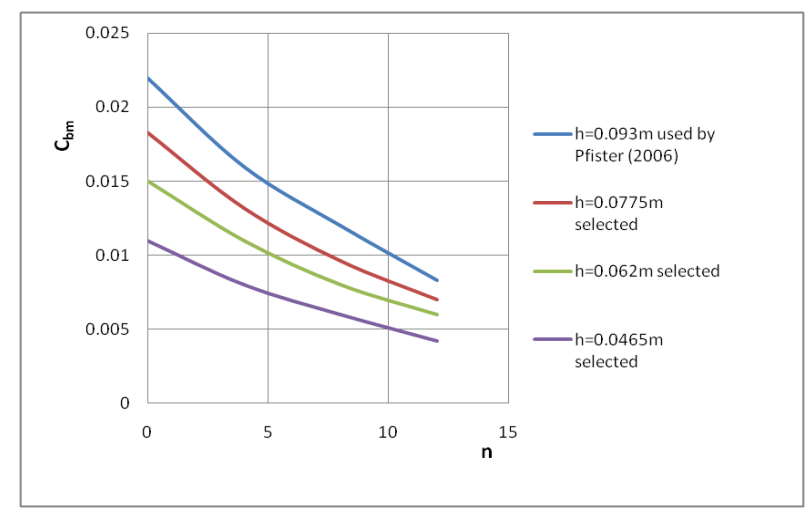

Figure 5. Variation of $\mathrm{C}_{\mathrm{bm}}$ with step number for $\mathrm{q}=0.866$ $\mathrm{m}^{3} / \mathrm{s} \cdot \mathrm{m}$.

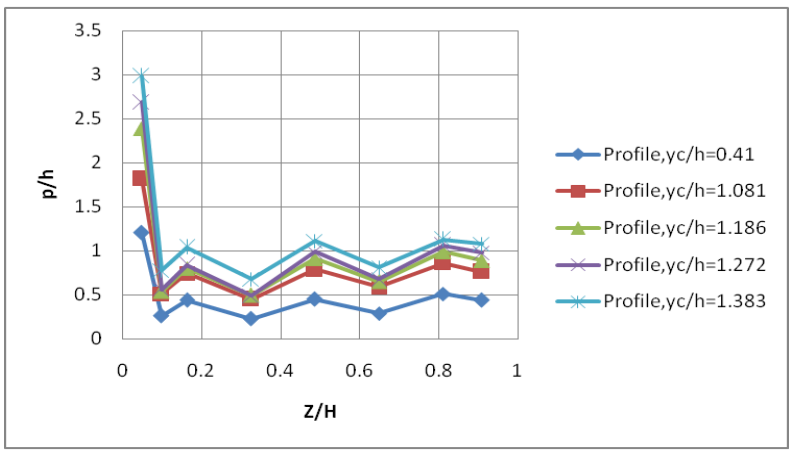

Figure 6. Mean pressure profiles on stepped spillway model.

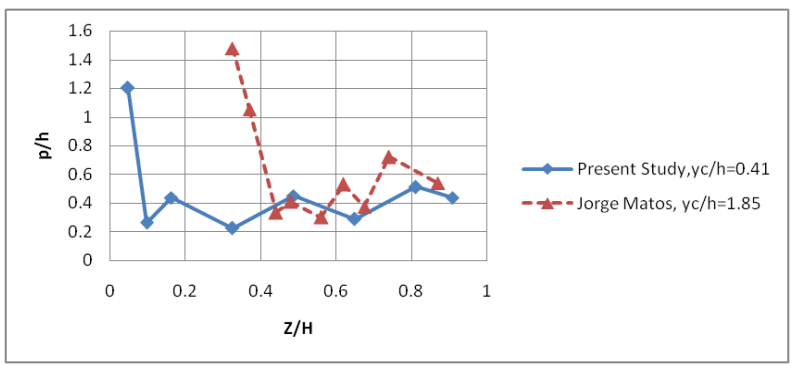

Figure 7. Comparison of observed mean pressure profile with calculated values by Jorge Matos method. 
pressure profiles observed in present study and study conducted by Jorge Matoes. In both the cases, pressure profiles (p/h) exhibit a wavy pattern down the stepped chute. Further, the pressure on each step increases with increase in $\mathrm{yc} / \mathrm{h}$ value. The differences in the value of $\mathrm{Z} / \mathrm{H}$ for these two profiles are due to different locations of measurement of pressure and different values of $\mathrm{y}_{\mathrm{c}} / \mathrm{h}$.

\section{Conclusion}

It is observed that air concentration increases with discharge as well as with number of step. Air concentration increases along the length of spillway. It is also observed that the bottom mean air concentration increases with step height in the upstream reach of stepped spillway, which is prone to cavitation. The pressure profiles exhibit a wavy pattern down the stepped chute. Further, the pressure on each step increases with increase in $\mathrm{y}_{\mathrm{c}} / \mathrm{h}$ value.

\section{References}

[1] Buwa, V.V. and Ranade, V.V. (2005) Characterization of Gas-Liquid Flows in Rectangular Bubble Columns Using Conductivity Probes. Chemical Engineering Communications, 192, 1129-1150. http://dx.doi.org/10.1080/009864490522704

[2] Boes, R.M. and Hager, W.H. (2003) Two-Phase Flow Characteristics of Stepped Spillways. Journal of Hydraulic Engineering, ASCE, 129, 661-670. http://dx.doi.org/10.1061/(ASCE)0733-9429(2003)129:9(661)

[3] Pfister, M., Hager, W.H. and Minor, H.E. (2006) Bottom Aeration of Stepped Spillways. Journal of Hydraulic Engineering, ASCE, 132, 850-853. http://dx.doi.org/10.1061/(ASCE)0733-9429(2006)132:8(850)

[4] Boes, R.M. (2000) Zweiphasenstrőmung and Energieumsetzung auf Grosskaskaden (Two Phase Flow and Energy Dissipation on Cascades). Ph.D. Thesis, VAW, ETH Zurich. (In German)

[5] Matos, J., Sanchez, M., Quintela, A. and Dolz, J. (1999) Characteristic Depth and Pressure Profiles in Skimming Flow over Stepped Spillways. Proceeding of the 28th IAHR World Congress, Graz, Session B14, 6 p. 